Article

\title{
Profiling End User of Renewable Energy Sources among Residential Consumers in Poland
}

\author{
Edyta Ropuszyńska-Surma $\mathbb{D}^{\mathbb{D}}$ and Magdalena Węglarz * $\mathbb{D}$
}

Faculty of Computer Science and Management, Wroclaw University of Science and Technology, 50-370 Wroclaw, Poland; edyta.ropuszynska-surma@pwr.edu.pl

* Correspondence: magdalena.weglarz@pwr.edu.pl

Received: 23 October 2018; Accepted: 22 November 2018; Published: 27 November 2018

\begin{abstract}
This paper investigates the profile of end user of renewable energy sources (RES) among Polish households. Users differ in their sex, age, economic status, knowledge about energy, their attitudes toward RES and pro-ecological behavior therefore our focus was on exploring segmentation criteria. The main determinants of willingness to install small-scale RES among households were assumed as segmentation criteria. The research identified the correlation between the households' willingness to install RES and (1) socio-economic and energy awareness variables, (2) pro-ecological and pro-effectiveness behaviors variables. The main determinants of RES adoption were explored using empirical analysis with data collected by the survey among 960 households in Lower Silesia, a southwest region in Poland in November and December of 2015. The importance of the variables was verified by a logit model. The discovery of the user profile is vital to obtain knowledge about users of small-scale generators to provide them personalized offer. The finding from this study could be valuable for local authority's energy utilities that are involved for increasing the adoption rate of RES among households and for (e.g., services companies installing RES) that are interested in increasing number of RES installations.
\end{abstract}

Keywords: consumer segmentation; end user profile; households; renewable energy sources (RES); pro-ecological behavior; energy awareness; prosumer

\section{Introduction}

In Poland, in the last 30 years, there has been a significant change in the structure of energy consumption in various sectors of the national economy. The share of households in overall electricity consumption in 1990 was $17 \%$, and 19\% in 2015 [1,2].

In Poland, households consume one-fifth of energy [3] and they are an important target group for climate and energy policies, especially since most of the energy comes from conventional sources. Only $13 \%$ of the energy consumed by households in Poland comes from renewable energy sources, and it is mainly the share of firewood. Other renewable energy sources either have an approximate share less than 1\% (e.g., solar or geothermal) or are unidentified (biomass energy) (cf. Reference [3]).

Additionally, the characteristics of changes in pollutant emissions into the atmosphere indicate that it was the companies that reduced the emissions of harmful substances to the greatest degree, rather than the households [4]. It is important to lower the $\mathrm{CO}_{2}$ emissions by households. In Poland, the high level of such pollution is the result of using outdated heating systems based on conventional fuels. This is an important issue in villages and some cities (e.g., Cracow), where inhabitants suffer from smog. Dispersed renewable energy sources (RES) intended for installation in households could be more developed in Poland.

These facts point to how important consumers of electricity and heat are households, which should be of interest to the energy policy makers (at national and local level), electricity and heat retailers, 
distributors, manufacturers and services of micro-installations of RES, e.g., photovoltaic cells, solar panels, heat pumps, wind turbines. From the perspective of each of these entities, segmentation of households and the identification of characteristic behaviors of households in key segments is important.

The purpose of the study is to explore the profile of households which want to become a prosumer. This paper investigates the main determinants of willingness to install small-scale RES among households using empirical data. The main determinants such as sex, age, floor area of building, and education level were adopted as segmentation criteria. Additionally, the paper presents pro-ecological and pro-effectiveness behavior of households, their attitude toward installing or not installing RES, their expectations and fears related to being a prosumer.

The contribution of the paper is threefold. Firstly, based on a literature review the main determinants of willingness to install small-scale RES among households were shortly described. Secondly, the proposal of segmentation criteria was made, which allowed distinguishing statistically important segments of households for installing micro-installations of RES in Poland. The macro-segmentation of the market of customers of RES installations was carried out together with showing their potential size in Poland. Next, the residential customer was chosen to explore micro-segmentation. The residential customers in Poland was explored in a more detailed way using the results of survey research to point out the factors influencing the willingness to install RES or to become a prosumer.

Finally, the profiling of main segments was prepared including the description of key features and households' behaviors. These results could be the guidelines for local authorities and other decision makers as well as for the producers and the deliverers of micro-installations of RES. In this way they could be a source of information for marketing actions.

The structure of the paper is as following: In Section 2 the literature is reviewed by discussing the thematic type of research related to characteristics of electricity consumers (households) as well as their willingness to pay for green energy (it is similar like willingness to pay for green tariffs) and willingness to install the RES micro-installations. Section 3 describes the research conducted in Poland (Lower Silesian voivodship) in 2015. In the first point of this section the research sample is presented-including its structure, the research purposes, the used research methods, and the structure of questionnaire. In the second point of this section the results linked to the characteristics of potential prosumers, persons who would like to become a prosumer in the future, is presented. Next, the results of the Chi-test made for researched features and pro-ecological behavior of households is shown. In third part of Section 3 these characteristics and behaviors are tested by using the logit model. Based on the statistical methods, the segmentation and profiling of households was made. Finally, in Section 5 the main results are summarized, as well as the recommendations for policy makers formulated.

\section{The Literature Review}

Taking into consideration the goal of this paper, residents' features influencing being or becoming a prosumer and/or installing micro-scale RES installations are crucial. There are almost no studies directly related to households' segmentation and profiling according to non-technical characteristics. Therefore, the recent research about testing households' features which affect their pro-ecological decisions (like adoption of RES technologies, higher willingness to pay (WTP) for a green energy or a green tariff) is the frame of this article, and they were key points for designing our survey. These studies have been carried out by the scientists coming from e.g., countries like: Sweden, Britain, Spain, Greece, Dania, Canada, China, and South Korea. The authors used such research methods as: Choice experiment [5], mixed logit model [6], Chi-square test or other statistical tests [6], contingent valuation method [7]. The main problem with focusing on the adoption of green technologies, in the most cases, is the fact that the respondents' declarations were investigated, but not their real behavior. Only the demographic features could be recognized as verified. To select the significant features, a desk research was made according to such topics as: The WTP for green (renewable electricity) or for green 
tariff, propensity to install RES, social acceptance for RES, and the identification of main characteristics prosumers or households having RES.

\subsection{Willingness to Pay for Green Energy (Renewable Electricity) or for Green Tariff}

The research related to willingness of households to pay extra for "green" energy was carried out e.g., by Batley, Colbourne, Fleming, and Urwig, who investigated the willingness to pay for green energy $[8,9]$. According to them, there is positive correlation between the WTP for renewable energy and such variables as: Income, the willingness to invest in energy efficient appliance energy efficiency of individuals and "social grouping." Shin and Hwang studied energy users, taking into account characteristic demographic variables (e.g., gender, age, education) and their propensity to pay for renewable fuels in the context of the renewable fuel policy in South Korea [10].

The approximation of WTP for renewable electricity among Beijing (one province in China) residents was carried out by Guo, Liu, Mao, Jin, Chen, Cheng [7]. They described that almost half of respondents had a negative attitude to the WTP for renewable electricity. The main reasons for this negative opinion were their low income, the belief that it is governments duty to develop renewable electricity, and the "lack of faith that the money would be used for the development of renewable electricity" [7]. They confirmed the positive correlation between the WTP for renewable electricity and the household income and the monthly electricity consumption. The negative correlation was between the WTP and bid price. Zarnikau [11] suggests that an important factor is the age of the respondents (the people under age 55 are more willing to pay than older persons). According to Zarnikau [11] and Wiser [12] the WTP for renewable energy is higher among households renting accommodation than consumers having own home. The literature review does not confirm that gender is the significant factor influencing the WTP for renewable energy (e.g., References [11,12]). Interesting research was completed by Rowlands et al. [13].

The Spanish scientists [5] confirmed that the WTP for renewable energies depends on: The consumers' negative past experiences connected with outages of energy supply; the level of education as expressing greater concern for greenhouse gases (GHS) emissions; and those who display energy saving behavior.

\subsection{Willingness (Propensity) to Install RES}

The effect of various factors on the decision to install RES in British households was shown by Scarpa and Willis [6]. They identified the barriers to installing micro-generation technologies, such as solar photovoltaic cells, micro-wind turbines, solar thermal cells, heat pumps, biomass boilers and pellet stoves. Using the logit model, they tested the importance of such factors characterizing British households as: Capital cost, energy bill per month, maintenance cost per year, recommendation by friends and/or by plumber, contract length, the inconvenience of system. This inconvenience could require e.g., a garden to be dug up during installation, refueling and space for fuel storage (e.g., biomass), or the space for a boiler. The vast majority of British households had not installed these technologies, due to high capital costs in comparison to annual savings in energy running costs. This fact evidences households' rationality.

\subsection{Social Acceptance for RES}

Carlman considered the problem regarding social acceptance for wind energy, in particular the social, political and regulatory framework surrounding the placement of wind turbines [14]. The results of her research show that there exist a significant number of barriers to social acceptance. Persuading local communities of the positive impact of such investments, together with obtaining the appropriate legal permission, lasts from 7 to 10 years. This research was developed by e.g., Bosley [15], who defined and analyzed problematic issues associated with the implementation of RES. Upham et al. [16] analyzed the main factors governing social acceptance for variance types of energy sources in Great Britain. In turn, Stackley [17] investigated social acceptance in Europe for the technologies for capturing and storing $\mathrm{CO}_{2}$. The level of social acceptance for solar energy has also 
been studied in the Chinese region of Shandong [18]. In Polish conditions, the research about green electricity adoption was conducted by Kowalska-Pyzalska [19].

\subsection{The Identification of Main Characteristics of Prosumers or Households Having RES}

In Poland, CSO reports on household energy consumption are published every three years. There is data on the structure of consumption of individual energy carriers, electrical equipment and household equipment for heating systems [3]. In 2015, surveys were conducted by the Consumer Federation on the barriers to the development of prosperity in Poland and the preconditions and the restrictions on the installation of RES [20]. Therefore some Polish universities have conducted research on Polish households and their energy consumption, e.g.,:

- Survey research linked to environment, energy saving, the energy consumption by households and opinion on energy-efficient construction was conducted in one region of northwestern Poland [21],

- Survey research partially related to the households' ecological behavior was conducted in one region of southeastern Poland [22],

- Survey research partially about energy awareness was conducted in Upper Silesia-the region in southern Poland [23].

\subsection{Identification of the Main Barriers to Installing RES or to Becoming a Prosumer}

In China, the most significant barriers to developing RES are the high price of these installations and the lack of available capital [7]. In Poland, according to the Consumer Federation, the main obstacles to installing RES by Polish households are [20] too high cost of RES installation and other things like: Too long payback period, the lack of information, the lack of advice, the lack of co-funding, and unclear legal regulation. In the wider issues were made research by Da Silva, Karnouskos, and Ilic. They identify the needs of the prosumers (households) in the context of Smart Grids development in Spain [24], e.g., to have comfortable access to information on different type of devices.

Summarizing the literature review it could be written that the factors increasing the acceptance for green energy and micro-installation of RES as well as WTP for them are: Consumer income, place of living (accommodation or own home), return of investment, education, ecological knowledge and awareness, and age.

Firstly, such research as WTP for green energy or social acceptance of RES made in Chinese, British or Swedish economy cannot be directly applied to assessing the readiness to install RES in Poland, since Polish society is characterized by a different mentality, culture, habits and, above all, economic conditions (income, possessions, wealth, savings and living costs), e.g., the UK is richer than Poland [6], so we can imagine that Polish households are not interested in using RES technologies. Secondly, in Poland this type of research was conducted on a small scale, while the decision makers need this type of research as related to current economic conditions of household. There are relatively few studies on profiling the energy consumers and most profiling studies describe the technical characteristics of consumers, not social ones. Thus, it was necessary to carry out a Polish survey, whose results are presented in this article. Our research is conducted according to a microeconomics approach and we try to identify not only typical demographic and economic factors influencing households' behaviour, but social factors and related psychological factors. It is not a popular and widely used approach to explore the behavior of individual energy consumers, i.e., households, but recently some researchers have studied e.g., households' behaviour, their willingness-to-pay for RES micro-installations [6], green energy [8] or the factors determining prosumers' behaviour [24] and they have taken into account the psychological features of individual energy consumers. 


\section{Materials and Methods}

\subsection{Design of Survey among Households in Poland}

The survey 'Modeling prosumers' behavior in the energy market' was conducted in November and December 2015. The research sample consisted of households from Lower Silesia (one of the regions in southwestern Poland), which covers $6.38 \%$ of the country's area, and is a place of residence for $7.56 \%$ of the Polish population [25]. The research sample was selected according to the stratified structure of the population of the Lower Silesian Voivodship according to criteria such as number of women and men, place of residence (poviats) and age of men and women in individual countries, distinguishing the following age brackets: 20-29 years, 30-49 years, 50-64 years and 65 and over. This sample selection reflected the gender and age structure of Lower Silesian poviats, so the sample was representative (see Figure 1). Additionally, the age structure of the sample, broken down by sex, corresponds to the structure of the Polish society [25]. Therefore, it allows for the extension of the conclusions to the entire population. The structure of respondents and Polish population structure by age and gender is presented in Table 1.

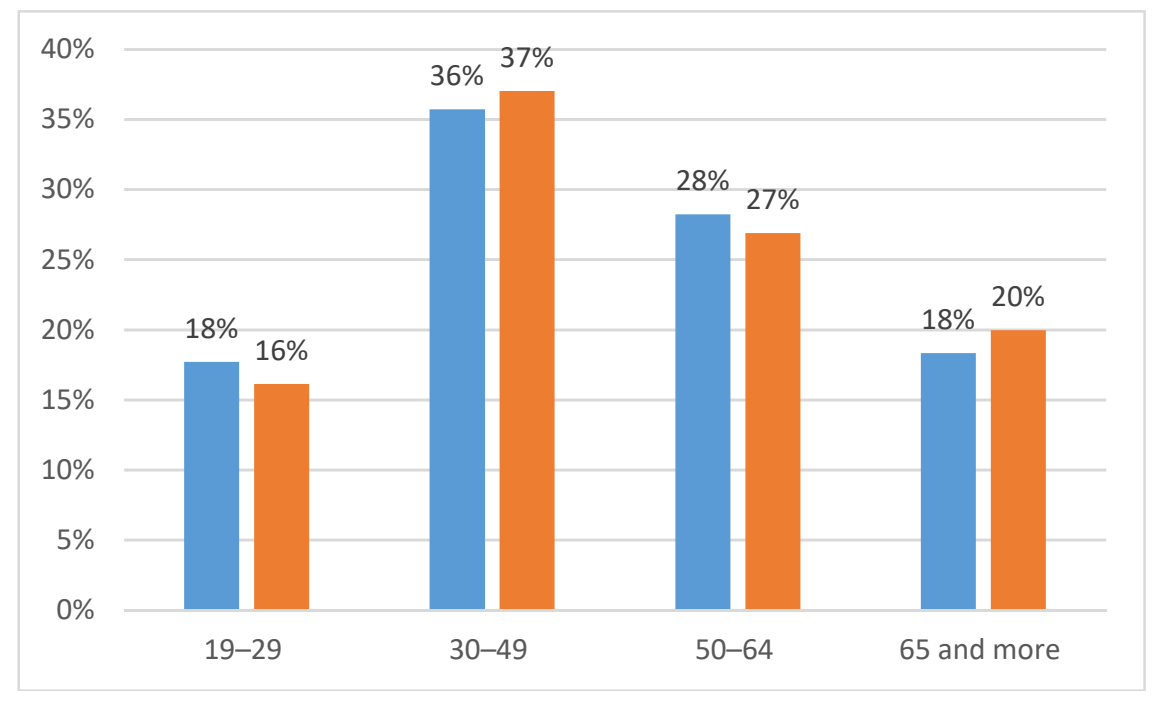

Figure 1. Age distribution of the sample and population of Lower Silesia.

Table 1. Sample structure according to sex and age.

\begin{tabular}{ccccccc}
\hline & \multicolumn{3}{c}{ The Research Sample } & \multicolumn{3}{c}{$\begin{array}{c}\text { The Polish Population in 2015 } \\
\text { (in Thousands) }\end{array}$} \\
\hline Age (in years) & Male & Female & F/M & Male & Female & F/M \\
\hline $19-29$ & 86 & 84 & 0.98 & 5348.7 & 2722.1 & 2626.5 \\
30-49 & 176 & 167 & 0.95 & $11,345.3$ & 5729.8 & 5615.5 \\
$50-64$ & 134 & 137 & 1.02 & 8025.8 & 3853.6 & 4172.2 \\
65 and over & 66 & 110 & 1.67 & 5968.5 & 2317.8 & 3650.7 \\
\hline
\end{tabular}

A pilot test of the survey was conducted before large scale implementation. The pilot study was conducted on a small subset of the sample (30 questionnaires) to fine tune the survey and to test its usefulness. A pilot version of the questionnaire was constructed in cooperation with a psychologist. Only some minor changes were made after this test to improve the clarity of several questions and response options. The size of the sample was determined on the basis of statistical data concerning the number of households and prosumers being natural and legal persons (data from Distribution System Operator). Assuming the confidence level was equal to $99 \%$ and the confidence interval to $3 \%$, particular numbers of households (1846) and prosumers (99) was obtained. Thus, the total size 
of the sample was calculated as 1945 respondents [26], but to survey a higher number was assumed. By telephone method, 2000 respondents, who were decision-makers in households, were surveyed. However, due to the incompleteness of some answers to different questions, only 960 questionnaires were categorized into the survey.

The questionnaire consisted of 34 questions, which could be divided into four groups: Demographic and social data, economic data, knowledge and awareness data and behavior and attitudinal data. The structure of the questionnaire and the objectives of each question group are shown in Figure 2. The questions were both closed (including selection cafeteria and open. Likert's scale (5th and 4th graders) was used in the questionnaire regarding the behavior and attitudes of the respondents.

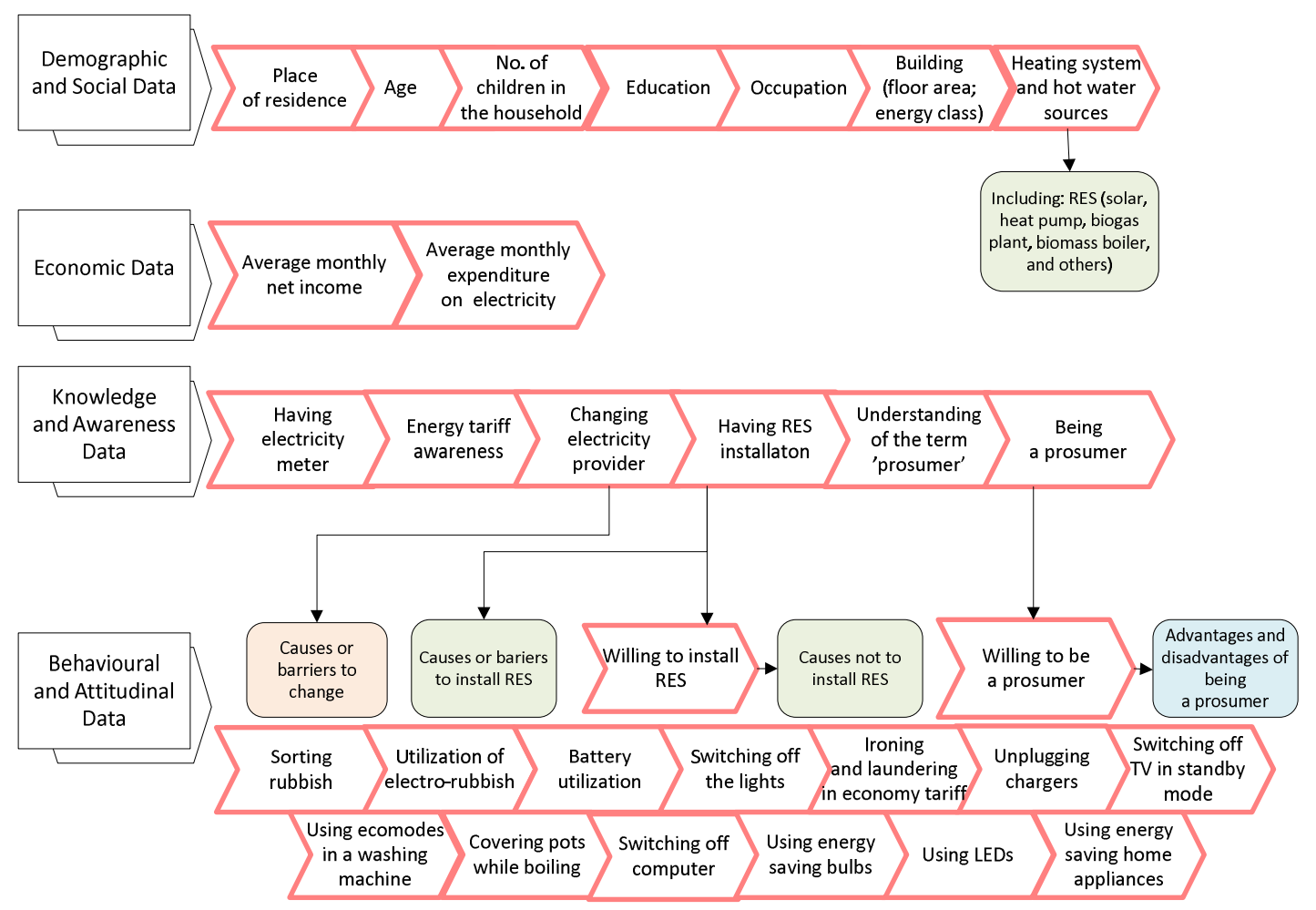

Figure 2. Structure of the survey.

The first group of questions concerned the demographic and social characteristics of respondents, including basic housing conditions (i.e., type of building, the area of the apartment, type of heating and hot water source). The second group of questions concerned economic aspects, i.e., monthly income and expenditure on electricity. It should be noted that $30 \%$ of the respondents did not answer the income question. Another group of questions was about knowledge and awareness concerning house energy aspects. The purpose of these questions was to check the extent to which respondents are aware of the opportunities they face today due to legal regulations concerning i.e., being a prosumer, or changing electricity providers. Additionally, to check to what extent they are open to new technical solutions, i.e., installing smart meters or micro-installations of RES. It is logical to assume that the question concerning knowledge about the tariff group reflects the level of the basic knowledge that a decision maker in the household would have, and entails a more informed choice of the tariff group. The 'knowledge and awareness' questions were linked to other supplementary questions that were assigned to the questionnaire part concerning 'behavior and attitudes' of the respondents. They were covering, among others, an indication of the reasons for the change of the electricity supplier or the failure to make such a change, the reasons for deciding to install RES or to abandon such a decision, or the desire to become a prosumer and indication of the benefits and disadvantages of 
being a prosumer. Such questions have allowed investigating the tendency of households to install RES and/or become prosumers, as well as to identify the attitudes of individual respondents toward RES installation and pro-consumerism. The analysis of attitudes and behaviors of the respondents was supplemented by a group of questions related to typical pro-ecological and pro-efficiency habits related to e.g., switching off the light (see Figure 2).

\subsection{Survey Results}

The main conclusions regarding the characteristics of respondents who became the basis for the selection of household segmentation criteria (Section 4.1) and the selection and further study of the characteristics of the target group are presented below.

Although electricity and heat are basic goods that meet many consumer needs for everyday living (e.g., lighting, communication, fun and entertainment, cleanliness, heating), the results confirm that awareness and knowledge about house energy is not the best among households, as evidenced by the number of positive responses in the 'knowledge and awareness' question group (see Table 2).

Table 2. Knowledge and awareness of households about the 'house' energy aspects.

\begin{tabular}{cccc}
\hline Questions Concerning Knowledge & Yes & No & $\begin{array}{c}\text { I Have Heard This Term, but Do } \\
\text { Not Know What It Means }\end{array}$ \\
\hline Know the tariff? & 118 & 842 & - \\
Have changed the provider? & 85 & 875 & - \\
Have a smart meter? & 267 & 693 & - \\
Know the term prosumer? & 72 & 858 & 30 \\
\hline
\end{tabular}

In addition, the survey identified the number of households with RES (45) micro-installations, the number of households that are willing to install RES (281) and the number of households that do not have RES and do not want to install them in the future (623). Numbers in parentheses determine the size of individual subgroups. A total of 11 people without RES have not answered the question whether they would like to have RES. Therefore, the sum of the answers given is smaller by 11 than the sample size.

In the group of 118 people who know their electricity tariff, only nine people have RES installations, and only 11 people know the term 'prosumer' (two people have heard the word 'prosumer', but they do not know its meaning). The relations between the group of people "who have or want to have RES" and who know their tariff, who have changed electricity suppliers, who has a smart meter and who know the term 'prosumer' was verified using statistical tests. The only significant relationship is between the group of people who know their tariff and the willingness to have RES. People who know their tariff have more willingness to install RES (Chi-square $(2)=15.438$ with $p$-value $<0.001)$.

Based on Chi-square tests, statistically significant relations were identified and presented in previous works [27,28]. In Reference [27] socio-economic variables were analyzed and there was a relationship identified between willingness to install RES and (1) sex, (2) age, (3) number of people in a household, (4) monthly average net income, (5) the floor area, (6) monthly expenditure on electricity and (7) level of education. The research presented in Reference [28] allowed the researchers to identify the correlation between pro-ecological and pro-effectiveness behaviors of households and their willingness to install RES. The significance of the factors influencing the RES installation was verified by a Chi-square test. Among pro-ecological and pro-effectiveness behaviors were of consequence: (1) The utilization of electro-rubbish, (2) using energy-saving lights (LED), (3) installing energy-saving household equipment, (4) sorting rubbish (garbage), (5) battery utilization, (6) switching off the lights, (7) washing or ironing at particular times. The significance of qualitative variables, which influence a household's decisions about the RES installation, was verified by the results of the logit model in Section 3.3. 
Over $64 \%$ of respondents always behave pro-ecologically. The lowest pro-ecological attitude was in the case of the utilization of electro-rubbish, where $16 \%$ of respondents never utilized electro-rubbish. In the case of pro-effectiveness behaviors, households' attitudes to washing or ironing at particular times and using eco-option in washing machine were analyzed. Depending on a one-time zone or two-time zones tariff, households' attitudes to washing and ironing were analyzed. Almost $60 \%$ of households do not have a two-time zone tariff, so they cannot use them during washing and ironing. Among the households which have a two-time zone tariff, $41 \%$ state they always wash or iron in particular times using cheaper energy. Almost $27 \%$ of households have the old type of washing machines, so they do not have eco-options. The rest of households have washing machines with eco-options. A total of $62.6 \%$ of them always use eco-options while washing clothes [28].

Another part of the analysis on pro-effectiveness behaviors concerned questions about dwelling equipment in energy-saving lights, LED lights bulbs, home appliances A+++. Over $70 \%$ of households own only older types energy-saving lights. Less than $46 \%$ of households own more energy efficient equipment, such as LED lights and home appliances A+++. A total of $18.5 \%$ of households own only LED lights, and $16.2 \%$ of households own only home appliances A+++ class.

\subsection{Verification of Survey Results by Logit Model}

A logit model was used for the analysis, because the endogenous variable is dichotomous. The aim of modelling the binomial variable is the forecast of the change in the probability of making a decision to install RES caused by a change in the value of one of the exogenous variables. While constructing the regression equation of the logit model, all socio-economic and energy awareness explanatory variables were included together in it (see Table 3), which may explain the behavior of the explained variable. Another model was created for explanatory variables related to pro-ecological or pro-efficiency attitudes of households. All explanatory variables were included in one logit model. Below are presented results of two logit models.

The calculations were made using the Gretl program. The level of significance was $95 \%$. Using the logit models, odds ratios were determined $O R=\exp \beta_{i}$, which is interpreted as a relative chance of occurrence of an event in a given subgroup in comparison with the reference group. At the same time, ranking does not allow the indication of differences in the odds ratios for individual categories of features, what was particularly important for age, expenditures and education (results of previous analyses for those variables are presented in Polish in Reference [29]). For this reason, explanatory variables were converted into $0-1$ regressors. The original nominal variable, with $\mathrm{k}$ variants, was transformed into k-1 artificial variables, and one of the variants was not introduced to the model but is a reference point (the so-called reference group) for other artificial variables.

The results of estimation of the logit model for socio-economic variables and energy awareness variable are presented in Table 4 . The explanatory variables such as income-In, changing the provider $-P$, understanding the prosumer term-Prosum and smart meter installed-SM were statistically insignificant ( $p$-value $>0.05$ ). Statistical significance was confirmed by the logit model in case of: (1) Sex, (2) number of people in a household $-F,(3)$ floor area- $F A,(4)$ type of building $-B$, (5) energy tariff awareness- $T$.

Some of artificial variables were not statistically significant $(p$-value $>0.05)$. The obtained results did not confirm previous assumptions about statistical significance between decision to install RES and monthly expenditure on electricity-Ex. However, the results confirmed statistically significant relationships between decision to install RES and (1) particular group of age 30-49 years- $A 2$, (2) particular groups of education levels; basic vocational-Edu3 and secondary-Edu4.

Then, using the logit model, explanatory variables such as pro-ecological or pro-efficiency attitudes of households were used to explain a household's decision about the RES installation. For this model, the odds ratios were also determined. The pro-ecological and pro-effectiveness behavior variables were multi-variant quality variables (take values from 0 to 6 or values from 0 to 3 ) and are presented in Table 5. 
Table 3. The exogenous us variables used in logit model.

\begin{tabular}{|c|c|c|c|c|}
\hline Variable & Description & Values & & Type of Variable \\
\hline Sex & sex of decision person & $\begin{array}{c}1=\text { female } \\
2=\text { male }\end{array}$ & $\begin{array}{l}51.95 \\
48.05\end{array}$ & binomial \\
\hline$F$ & number of people in a household & $\begin{aligned} & 1=1 \text { person } \\
& 2=2 \text { persons } \\
& 3=3 \text { persons } \\
& 4=4 \text { persons } \\
& 5=5 \text { persons } \\
& 6=6 \text { persons } \\
& 7=7 \text { and more persons }\end{aligned}$ & $\begin{array}{c}13 \\
30.7 \\
20.5 \\
20.3 \\
8.6 \\
4.1 \\
2.7\end{array}$ & $\begin{array}{c}1-9 \text { scale, } \\
\text { multi-variant }\end{array}$ \\
\hline In & monthly average net income & 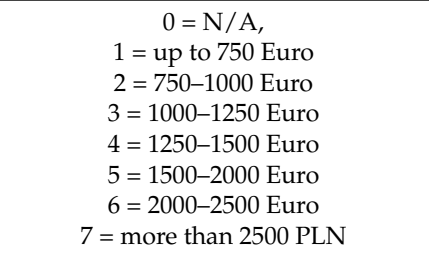 & $\begin{array}{c}32.2 \\
42.2 \\
13 \\
5.8 \\
2.9 \\
1.8 \\
0.8 \\
1.3\end{array}$ & $\begin{array}{c}0-7 \text { scale, } \\
\text { multi-variant }\end{array}$ \\
\hline$F A$ & the floor area & 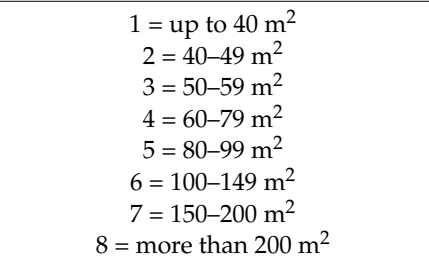 & $\begin{array}{c}6 \\
9.6 \\
14.2 \\
18.2 \\
15.7 \\
18.9 \\
11.4 \\
6\end{array}$ & $\begin{array}{c}1-8 \text { scale, } \\
\text { multi-variant }\end{array}$ \\
\hline$B$ & type of building & $\begin{array}{c}1=\text { detached house } \\
2=\text { multifamily }\end{array}$ & $\begin{array}{l}49.2 \\
50.8\end{array}$ & binomial \\
\hline$T$ & energy tariff awareness & $\begin{array}{l}1=\text { yes } \\
2=\text { no }\end{array}$ & $\begin{array}{l}12.3 \\
87.7\end{array}$ & binomial \\
\hline$P$ & changing the provider & $\begin{array}{l}1=\text { yes } \\
2=\text { no }\end{array}$ & $\begin{array}{c}8.9 \\
91.1\end{array}$ & binomial \\
\hline Prosum & understanding of the term 'prosumer' & $\begin{array}{c}1=\text { no } \\
2=\text { not sure } \\
3=\text { yes }\end{array}$ & $\begin{array}{c}89.2 \\
3.2 \\
7.6\end{array}$ & $\begin{array}{c}1-3 \text { scale, } \\
\text { multi-variant }\end{array}$ \\
\hline$S M$ & smart meter installed & $\begin{array}{l}1=\text { yes } \\
2=\text { no }\end{array}$ & $\begin{array}{l}27.6 \\
72.4\end{array}$ & binomial \\
\hline$A$ & age of decision person & $\begin{array}{c}19-29(A 1) \text { reference group } \\
\text { 30-49 }(A 2) \\
50-65(A 3) \\
\text { more than } 65 \text { years }(A 4)\end{array}$ & $\begin{array}{c}17.8 \\
35.9 \\
28 \\
18.2\end{array}$ & artificial \\
\hline$E x$ & monthly expenditure on electricity & $\begin{array}{l}\text { up to } 12.5 \text { Euro }(E x 1) \text { reference group } \\
\text { 12.5-25 Euro }(E x 2) \\
\text { 25-50 Euro }(E x 3) \\
\text { 50-75 Euro }(E x 4) \\
\text { more than } 75 \text { Euro }(E x 5)\end{array}$ & $\begin{array}{c}7.6 \\
33.1 \\
38.6 \\
12.4 \\
8.3\end{array}$ & artificial \\
\hline$E d u$ & level of education & $\begin{array}{c}\text { undefined or below primary }(E d u 1) \\
\text { reference group } \\
\text { primary }(E d u 2) \\
\text { basic vocational }(E d u 3) \\
\text { secondary }(E d u 4) \\
\text { tertiary }(E d u 5)\end{array}$ & $\begin{array}{c}3.2 \\
2.6 \\
18 \\
42 \\
34.2\end{array}$ & artificial \\
\hline
\end{tabular}

The results of estimation of the logit model for pro-ecological and pro-efficiency attitudes variables are presented in Table 6. The obtained model did not confirm significance of qualitative variables, such as the utilization of electro-rubbish-UE, battery utilization- $U B$, switching off the lights- $L$, using eco-options in washing machine-Eco.

It was observed that significant relationships exist between a household's decisions about the RES installation and (1) sorting rubbish $-S,(2)$ washing or ironing at particular times-W, (3) switching off electrical equipment (e.g., computer) if nobody uses-K, (4) using LEDs—LED, and (5) installing energy-saving home appliances-HA. 
Table 4. The results of estimation of logit model for socio-economic and energy awareness variables.

\begin{tabular}{|c|c|c|c|c|c|}
\hline Variable & Coefficient & $p$-Value & Significance Level & Marginal Effect & Odds Ratio \\
\hline $\operatorname{Sex}$ & 0.4189 & 0.0153 & ** & 0.0834 & 1.5203 \\
\hline$F$ & 0.1887 & 0.0036 & $* * *$ & 0.0008 & 1.2077 \\
\hline In & 0.0040 & 0.9467 & & 0.0829 & 1.0041 \\
\hline$F A$ & 0.4163 & $<0.00001$ & $* * *$ & -0.2541 & 1.5163 \\
\hline$B$ & -1.2757 & $<0.00001$ & $* * *$ & -0.1529 & 0.2792 \\
\hline$T$ & -0.7675 & 0.0018 & $* * *$ & 0.0479 & 0.4642 \\
\hline$P$ & 0.2404 & 0.4378 & & 0.0082 & 1.2718 \\
\hline Prosum & 0.0411 & 0.7893 & & 0.0432 & 1.0420 \\
\hline$S M$ & 0.2170 & 0.2562 & & 0.0994 & 1.2424 \\
\hline$A 2$ & 0.4988 & 0.0432 & $* *$ & 0.0152 & 1.6468 \\
\hline$A 3$ & 0.0763 & 0.7706 & & -0.0236 & 1.0793 \\
\hline$A 4$ & -0.1184 & 0.6995 & & -0.0455 & 0.8883 \\
\hline$E x 2$ & -0.2285 & 0.6097 & & -0.0211 & 0.7957 \\
\hline Ex3 & -0.1059 & 0.8130 & & -0.0361 & 0.8995 \\
\hline Ex4 & -0.1811 & 0.7132 & & -0.1551 & 0.8343 \\
\hline Ex5 & -0.7785 & 0.1483 & & 0.2034 & 0.4591 \\
\hline$E d u 2$ & 1.0209 & 0.1807 & & 0.2366 & 2.7756 \\
\hline$E d u 3$ & 1.1879 & 0.0401 & $* *$ & 0.2628 & 3.2802 \\
\hline$E d u 4$ & 1.3191 & 0.0191 & $* *$ & 0.1939 & 3.7400 \\
\hline Edu 5 & 0.9734 & 0.0875 & * & 0.0376 & 2.6470 \\
\hline
\end{tabular}

Note: ${ }^{* * *} p<0.01,{ }^{* *} p<0.05,{ }^{*} p<0.1$.

Table 5. The exogenous variables used in logit model.

\begin{tabular}{|c|c|c|}
\hline Variable & Description & Values \\
\hline$S$ & sorting rubbish & 0-6 scale, \\
\hline$U E$ & the utilization of electro-rubbish & $0=$ does not apply, \\
\hline$U B$ & battery utilization & $1=$ never \\
\hline$L$ & switching off the lights & $2=$ very rarely, \\
\hline$W$ & washing or ironing at particular times & $3=$ rarely \\
\hline Eco & using eco-options in washing machine & $4=$ often \\
\hline$K$ & $\begin{array}{l}\text { switching off electrical equipment } \\
\text { (e.g., computer) if nobody uses }\end{array}$ & $\begin{array}{c}5=\text { very often } \\
6=\text { always }\end{array}$ \\
\hline LED & using LEDs & $\begin{array}{c}0-3 \text { scale, } 0=\text { I have no such devices, } \\
1=\text { I have, but there are a few, }\end{array}$ \\
\hline$H A$ & installing energy-saving home appliances $(\mathrm{A}+++)$ & $\begin{array}{c}2 \text { = I have a lot of these devices, } \\
3 \text { = I have only such devices }\end{array}$ \\
\hline
\end{tabular}

Table 6. The results of estimation of logit model for household's behavior variables.

\begin{tabular}{cccccc}
\hline Variable & Coefficient & $p$-Value & Significance Level & Marginal Effect & Odds Ratio \\
\hline$S$ & 0.1089 & 0.0178 & $* *$ & 0.0241 & 1.1151 \\
$U E$ & 0.0485 & 0.2241 & & 0.0107 & 1.0497 \\
$U B$ & -0.0478 & 0.3029 & & -0.0106 & 0.9533 \\
$L$ & -0.0660 & 0.2657 & $* * *$ & -0.0146 & 0.9361 \\
$W$ & 0.1058 & 0.0067 & & 0.0234 & 1.1116 \\
$E c o$ & 0.0261 & 0.3747 & $* * *$ & 0.0058 & 1.0265 \\
$K$ & 0.0998 & 0.0033 & $* * *$ & 0.0221 & 1.1049 \\
$L E D$ & 0.2699 & 0.0000 & $* * *$ & 0.0598 & 1.3098 \\
$H A$ & 0.1876 & 0.0048 & 0.0416 & 1.2063 \\
\hline \multicolumn{7}{c}{ Note $* * *<<0.01^{* *} p<0.05^{*} p<0.1$} \\
\end{tabular}

\subsection{The Main Determinants of Becoming a Prosumer-Summary of the Results}

The logit model results confirmed that significant relationships exist between a household's decisions about the RES installation and thirteen explanatory variables-the main determinants of 
becoming a prosumer. For socio-economic and energy awareness variables, a higher relative chance of making a decision about installing RES is in case of:

- Decision making person in the household is a man, the chance is higher by $52 \%$,

- Decision making person in household is in age $30-49$, the chance is higher by $65 \%$,

- Decision making person in household has basic vocational (higher by $228 \%$ ) or secondary education level (higher by $274 \%$ ),

- Increasing the floor area, is higher on average by $52 \%$,

- Living in a detached house, higher by $72 \%$,

- Increasing the number of people in a household, is higher on average by $21 \%$,

- Knowing energy tariff, higher by $54 \%$.

For pro-ecological or pro-efficiency attitudes variables, a higher relative chance of making a decision about installing RES is by households which more often behave pro-ecologically than by a household which does not concern this behavior. A higher relative chance of making a decision about installing RES is for:

- Sorting rubbish (the relative chance increases by, on average, $12 \%$ ),

- Washing or ironing at particular times (the relative chance increases by, on average, $11 \%$ ),

- $\quad$ switching off electrical equipment (e.g., computer) if nobody uses (the relative chance increases by, on average, $10 \%)$,

- $\quad$ using LEDs (the relative chance increases by, on average, $31 \%$ ),

- installing energy-saving home appliances (the relative chance increases by, on average, $21 \%$ ).

The criteria of market segmentation was formulated on the basis of main determinants of becoming a prosumer which were confirmed by the logit model. Particular steps of micro-segmentation are based on socio-economic variables such as sex, floor area, age and education level.

In the case of type of building, there was a correlation between this variable and floor area. Living in single-family houses was identical with living in an area of more than $80 \mathrm{~m}^{2}$, consequently to segmentation was selected only one of them-floor area.

In the case of level of education, the results of the logit model confirmed a significant relationship between this variable and willingness to install RES. The highest chance to install RES is a household where the decision making person has basic vocational or secondary education. However, the percentage analysis conducted in works [27-31] (see Figure 3) suggested the relationship between technical education and willingness to install RES. Chi-square test analysis (Chi-square $(8)=21.633$ with $p$-value $<0.006$ ) confirmed a significant relationship between level of education and willingness to install RES. Among households where the decision maker has graduated from secondary technical education, $40.6 \%$ are willing to install RES or have RES installation. This indicates the potential to expand among this group, which has the technical ability to appreciate RES, but do not possess the technical or financial means to install RES. Figure 4 indicates that there exists a positive association between having studied a technical educational and installing an RES. Comparing households whose decision maker had a technical education with general education for both secondary or tertiary ones, it can be seen that a higher percentage of households were inclined to install RES in the case of technical education. Therefore, the education level (technical or nontechnical) was assumed as the fourth segmentation criteria. 

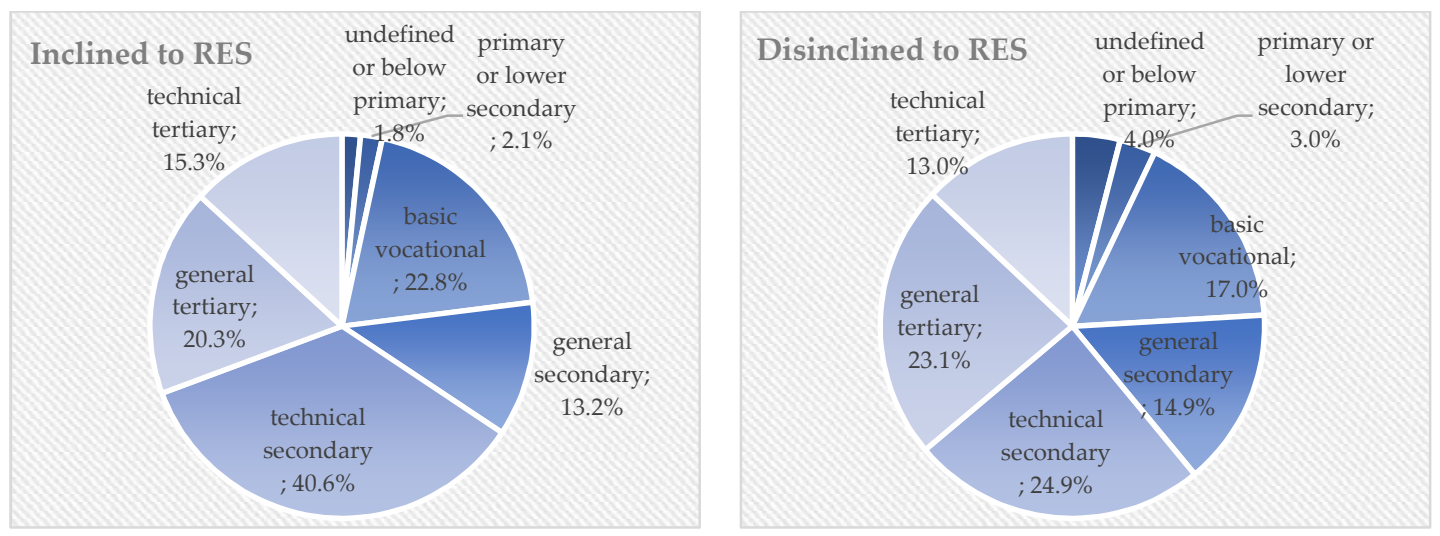

Figure 3. Structure of level of education and willingness to install RES.

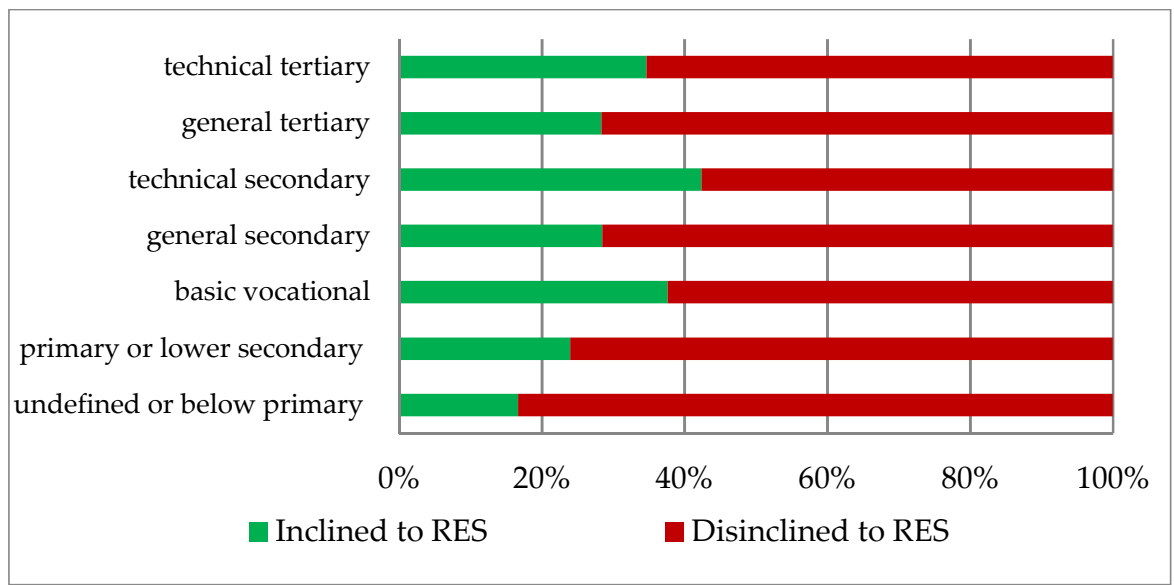

Figure 4. Structure of level of education and willingness to install RES.

\section{Profiling of the Prosumers}

\subsection{Criterion of Market Segmentation}

The macro-segmentation of the market of customers of RES micro-installations in Poland can be carried out due to the type of user of RES installation. Each segment will differ in the decision-making process, the possibility or lack of possibility of 'shifting' the investment outlays to other entities, the installed capacity and the applicable legal provisions concerning the installation procedures for RES and the possibility for resale of electricity produced from this installation to distribution company. In Poland, there are different procedures concerning entrepreneurs and individuals who install RES micro-installations. Only in the latter case, one can speak about a prosumer. In Figure 5, the segmentation of the audience according to the criterion 'type of entity' was proposed. The potential size of individual segments in Poland was also indicated.

The first segment is created by micro-entrepreneurs, the second one is created by the owners of public buildings, i.e., offices, schools, hospitals and other facilities. The third macro-segment is created by households, which are firstly divided into those that do not engage in farming activities (i.e., they are not agricultural) and those that are the agricultural households. There are over 9 million households in Poland [31]. Nearly 50\% of households (non-agricultural) live in single-family or semi-detached homes, so they can afford to install RES [32]. The additional potential is created by agricultural households. There are over 4.4 million of them [33]. It is clear that the potential for micro-installations of RES in the household segment is around 8.9 million. Moreover, according to Bargiel et al. [34], urban households report about 17,000 GWh of electricity demand and rural farms of about 10,000 GWh. 


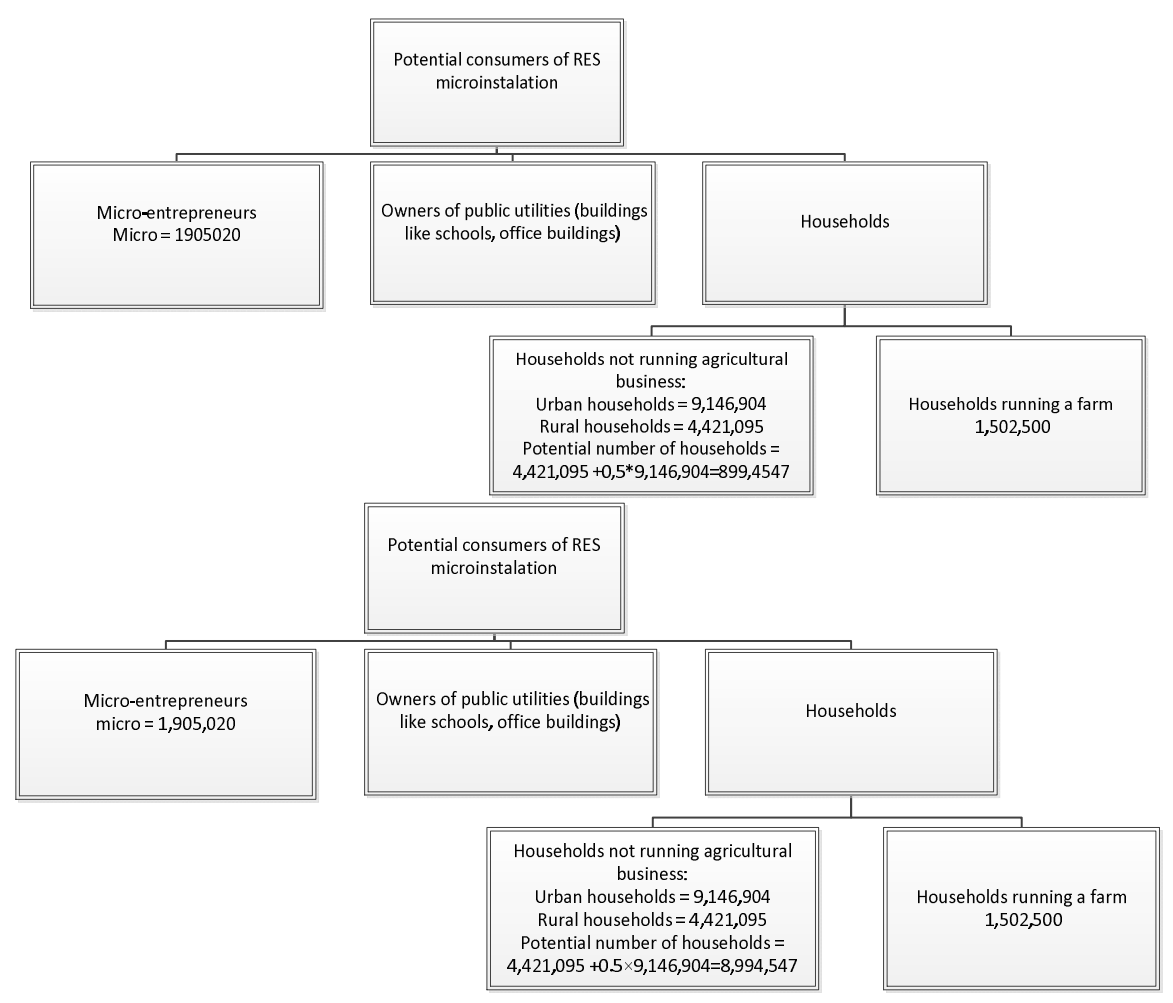

Figure 5. Macro-segmentation of consumers of RES micro-installation.

As noted in the introduction, the purpose of the study is to explore the profile of households which want to install RES. Households with the highest level of willingness to install RES are those where the decision making person is a man in age of 30 to 49 years with technical education, living in single-family houses with an area of more than $80 \mathrm{~m}^{2}$ (see Section 3). The following section presents the characteristics and behavior of this group of respondents compared to the similar group of men but with non-technical education. Figure 6 shows the sample size for micro-segments according to the presented above criteria.

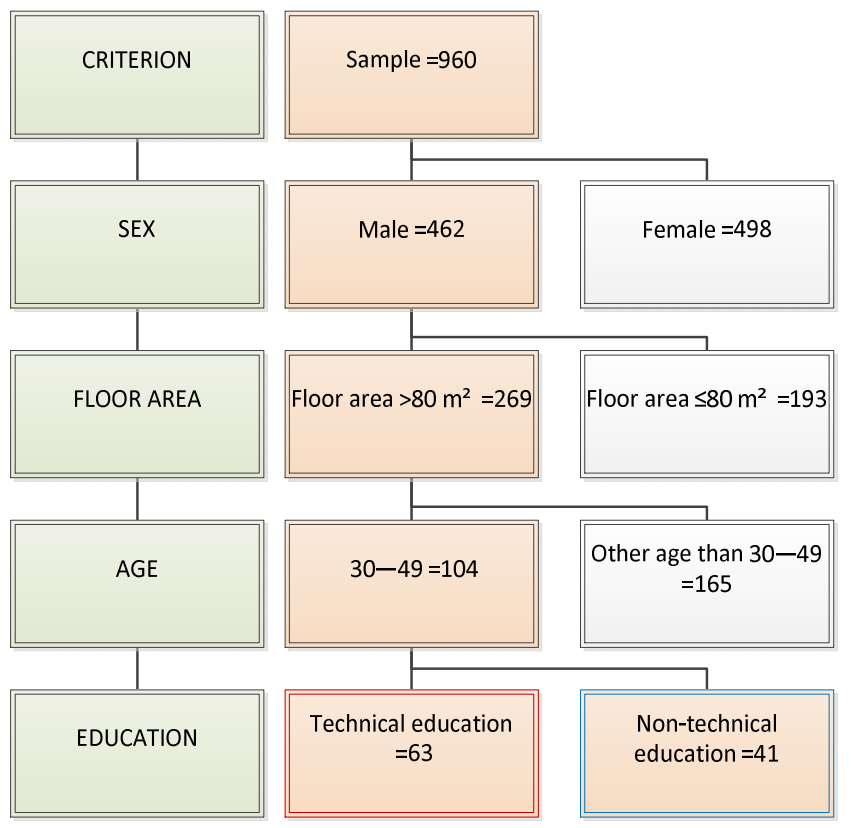

Figure 6. Micro-segmentation of target households. 


\subsection{Results of Segmentation-Behavior of Households (Residential Consumers)}

In selected segments, i.e., men with technical education (hereinafter referred to as $\mathrm{T}$ segment) and non-technical (NT segment), the behavior and attitudes of respondents were examined. Comparing the knowledge of $\mathrm{T}$ and NT respondents, a higher percentage of men with technical education know their tariff group (26.8\%) than those with non-technical education (12.2\%). Moreover, the knowledge of the tariff group was statistically significant in the case of the willingness to install RES (cf. Section 3). Figure 7 shows the percentages of respondents that have knowledge about home energy aspects for the T segment and the NT segment.

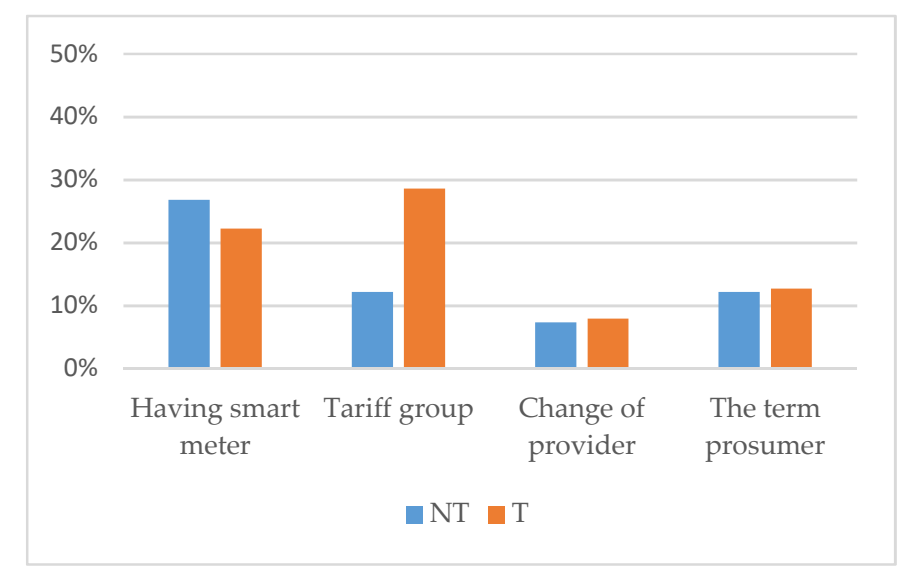

Figure 7. Knowledge and awareness of home energy aspects depending in the men with technical education (T) and men with non-technical education (NT) segment.

The other group of variables tested was those belonging to behavior and attitudes. Figures 8 and 9 show the percentage of respondents with LEDs and A+++ appliances in the T and NT segment, respectively.

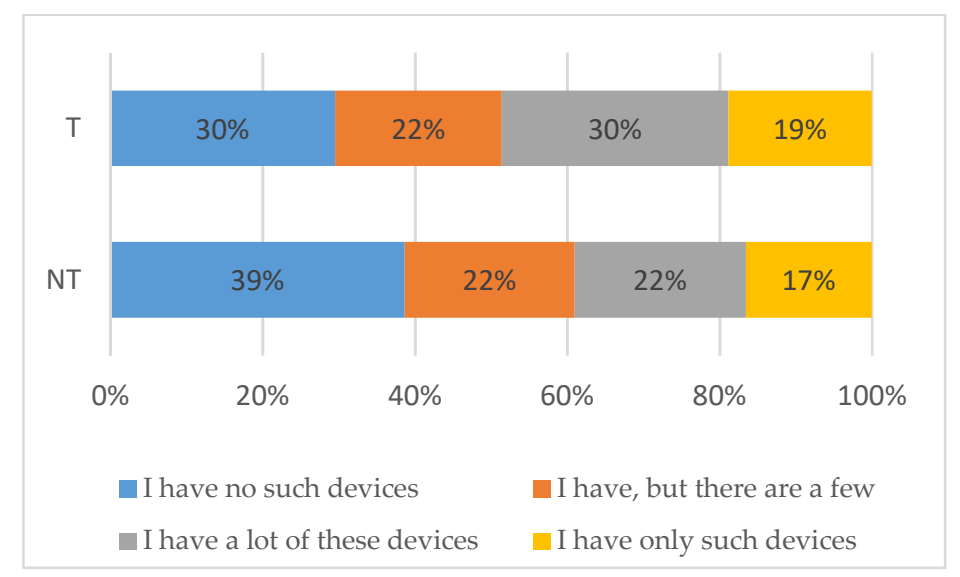

Figure 8. Percentage of respondents with LED bulbs in the T and NT segment.

People in the T segment use a larger percentage of LED lighting and energy-efficient appliances. In addition, $48.6 \%$ of people in the T segment have mostly or only LED bulbs, and in the NT segment, only $39 \%$ declares that. In turn, $34.9 \%$ of households in the T segment and $28.8 \%$ of the NT segment declared that they have mostly or only $\mathrm{A}+++$ appliances. It is clear that people with a technical education are more likely to shop for more energy efficient home appliances.

Table 7 shows the percentage of respondents in both segments declaring that they always exhibit specific environmental behaviors and Figure 10 presented frequency of particular declared pro-ecological behaviors. 


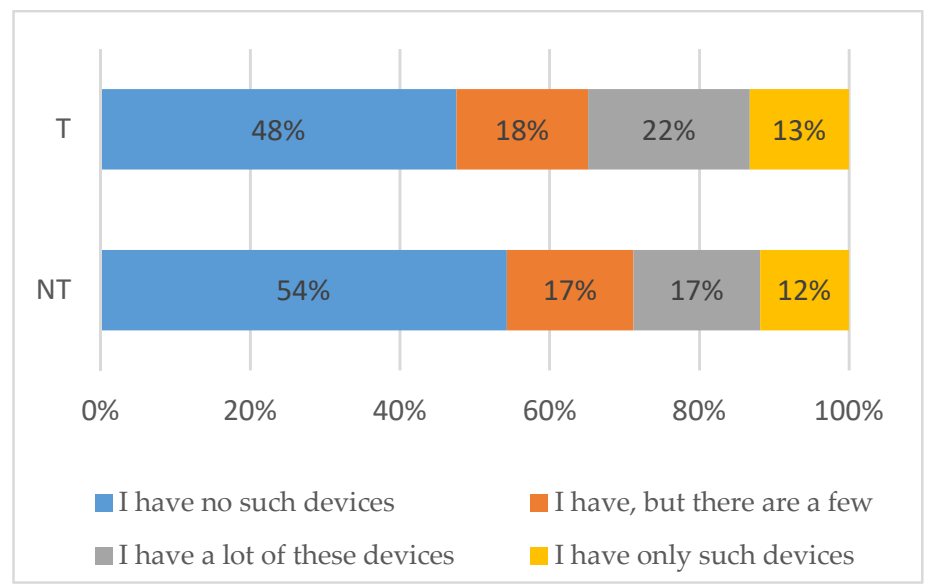

Figure 9. Percentage of respondents with $\mathrm{A}+++$ appliances in the T and NT segment.

Table 7. Percentage of men declaring that they always behave pro-ecologically (with segments breakdown) (\%).

\begin{tabular}{ccc}
\hline Declared Behaviour & Segment T & Segment NT \\
\hline Sorting rubbish & 70.0 & 71.0 \\
Washing or ironing at particular times & 15.4 & 17.8 \\
Switching off electrical equipment & 69.6 & 66.3 \\
(e.g., computer) if nobody uses & & \\
\hline
\end{tabular}

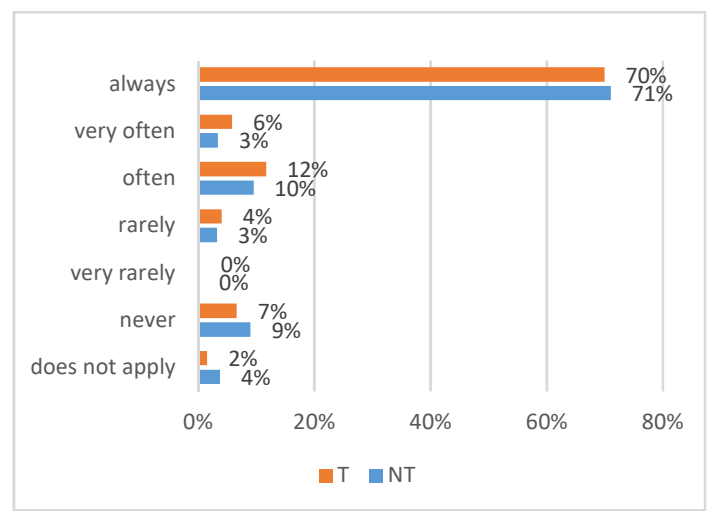

(a)

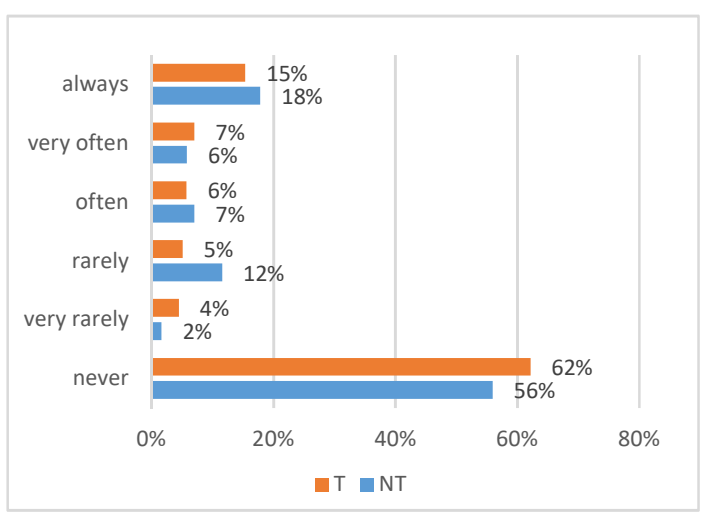

(b)

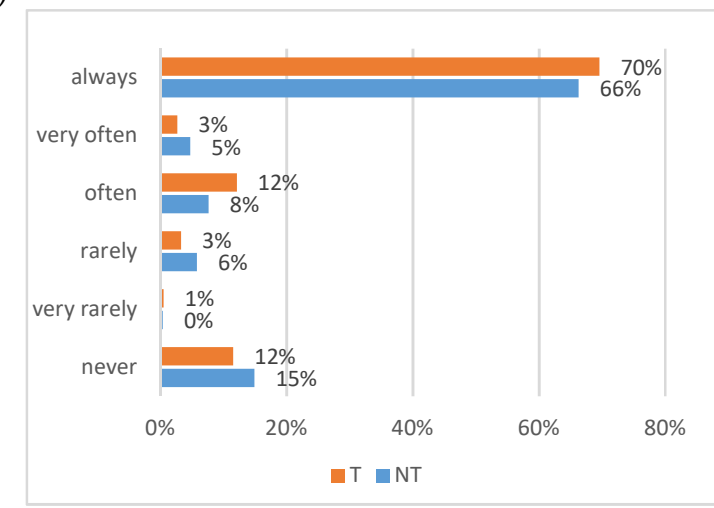

(c)

Figure 10. Percentage of respondents declaring behavior related to (a) sorting rubbish, (b) washing or ironing at particular times, (c) switching off electrical equipment (e.g., computer) if nobody uses. 
It is clear that a higher percentage of people in the NT segment is almost always pro-ecological. Only in regard to switching off electrical equipment, the relationship is opposite. It is difficult to pinpoint the cause of such differences, but it can be argued that people with more humanistic education be more sensitive to environmental aspects than people with technical education, but more in-depth research should be done.

In the case of sorting rubbish only $4 \%$ in NT segment and $2 \%$ in $\mathrm{T}$ segment declared that they did not care about environment. In case of washing or ironing at particular times, almost $60 \%$ of households do not have a two-time zone tariff, so they cannot use it. The percentage values for NT and T segments were respectively $56.7 \%$ and $60.3 \%$. Among the households that have a two-time zone tariff (see Figure 10b) never wash or iron at particular times, $62 \%$ of them in the T segment and $56 \%$ in the NT segment. In the case of switching off electrical equipment if nobody uses, respectively $13.5 \%$ and $7.9 \%$ of households in the NT and T segments declared that this problem did not apply to them, probably they do not have a computer. In this case, more pro-ecological behavior was demonstrated in the T segment.

\subsection{Results of Segmentation-Attitudes of Households (Residential Consumers)}

In the group of questions concerning behavior and attitude, the respondents were asked to indicate the reasons for installing or not installing RES (Tables 8 and 9); factors that motivate to be a prosumer (Table 10) and those who have influenced the decision that the respondent is not and does not want to be a prosumer in the future (Table 11). Respondents were also asked to indicate the benefits and disadvantages of being a prosumer (Tables 12 and 13). All questions were semi-open questions. Based on pilot studies, several options were selected. The respondent was also given the opportunity to provide his/her own answer. These were multiple choice questions. Tables 8-13 present the most commonly reported responses by the T and NT segment.

Table 8. Reasons for installing RES.

\begin{tabular}{cc}
\hline T Segment & NT Segment \\
\hline Long-term saving $(7.9 \%)$ & Long-term saving $(7.3 \%)$ \\
I feel like an ecologist $(3.2 \%)$ & - \\
\hline
\end{tabular}

Table 9. Reasons for not installing RES.

\begin{tabular}{cc}
\hline T Segment & NT Segment \\
\hline Lack of financial resources $(27 \%)$ & Lack of financial resources $(34.1 \%)$ \\
Too expensive comparing to the source used now $(9.5 \%)$ & Too expensive comparing to the source used now $(9.8 \%)$ \\
Lack of knowledge $(6.3 \%)$ & Lack of knowledge $(2.4 \%)$ \\
Technical reasons $(7.9 \%)$ & Technical reasons $(2.4 \%)$ \\
Lack of time $(3.2 \%)$ & Lack of need $(2.4 \%)$ \\
Financially inefficient $(7.9 \%)$ & \\
\hline
\end{tabular}

Table 10. Reasons for being a prosumer.

\begin{tabular}{cc}
\hline T Segment & NT Segment \\
\hline Long-term savings $(12.7 \%)$ & Long-term savings $(9.8 \%)$ \\
Financial benefits $(9.5 \%)$ & Financial benefits $(7.3 \%)$ \\
Openness to technical novelties $(7.9 \%)$ & Openness to technical novelties $(2.4 \%)$ \\
Convinced by specialist $(3.2 \%)$ & Favorable regulations $(2.4 \%)$ \\
Possibilities of co-funding $(4.8 \%)$ & \\
\hline
\end{tabular}

Summarizing all answers, men in the $\mathrm{T}$ segment have more knowledge of the pros and cons of becoming a prosumer, which is in line with the declared proficiency of the prosumer concept. Regarding the reasons for installing RES, respondents pointed to long-term savings, only a small part of them pointed to ecology. Both segments indicated the lack of financial resources, too expensive 
comparing to the energy source used now, the lack of knowledge and technical reasons as the reasons for not installing RES. However, lack of knowledge and technical reasons are most important for the T segment. The entire NT segment has not indicated that the reason for not installing RES is financial inefficiency.

Table 11. Reasons for reluctance to being a prosumer.

\begin{tabular}{cc}
\hline T Segment & NT Segment \\
\hline High installation costs $(20.6 \%)$ & High installation costs $(24.4 \%)$ \\
Complicated installation process $(12.7 \%)$ & Complicated installation process $(17.1 \%)$ \\
Unclear legal regulations $(12.7 \%)$ & Unclear legal regulations $(4.9 \%)$ \\
Lack of possibility $(9.5 \%)$ & Lack of possibility $(12.2 \%)$ \\
Financially inefficient $(7.9 \%)$ & Financially inefficient $(4.9 \%)$ \\
Lack of interest $(6.3 \%)$ & Lack of interest $(9.8 \%)$ \\
Lack of knowledge $(6.3 \%)$ & Lack of knowledge $(2.4 \%)$ \\
Lack of need $(1.6 \%)$ & Lack of need $(2.4 \%)$ \\
Lack of time $(3.2 \%)$ & Lack of financial assets $(2.4 \%)$ \\
Neighbors' opinion $(3.2 \%)$ & \\
\hline
\end{tabular}

Table 12. Advantages of being a prosumer.

\begin{tabular}{cc}
\hline T Segment & NT Segment \\
\hline Lower charges, savings $(12.7 \%)$ & Lower charges, savings $(9.8 \%)$ \\
Financial benefits $(6.3 \%)$ & Financial benefits $(2.4 \%)$ \\
Own needs $(1.6 \%)$ & Own needs $(7.3 \%)$ \\
Environmental benefits $(1.6 \%)$ & Environmental benefits $(2.4 \%)$ \\
Financial and environmental benefits $(1.6 \%)$ & \\
Independence $(3.2 \%)$ & \\
\hline
\end{tabular}

Table 13. Disadvantages of being a prosumer.

\begin{tabular}{cc}
\hline T Segment & NT Segment \\
\hline Neighbors' jealousy $(14.3 \%)$ & Neighbors' jealousy $(14.6 \%)$ \\
Financial costs $(7.9 \%)$ & Financial costs $(2.4 \%)$ \\
Small subsidies $(3.2 \%)$ & Noise $(2.4 \%)$ \\
Noise $(1.6 \%)$ & \\
\hline
\end{tabular}

Financial factors and the possibility of savings are the greatest incentives for setting up RES installations and being a prosumer for all respondents. Regarding the reasons for being a prosumer, no one in the NT segment has chosen possibilities of co-funding and influence of expert opinion, conversely no one in the $\mathrm{T}$ segment has chosen favourable regulations.

Among the barriers to becoming a prosumer, all respondents pointed to high installation costs, complicated installation process and the lack of technical possibility. Mostly the T segment indicated such factors as unclear legal regulations, financial inefficient, the lack of knowledge and influence of neighbors, what clearly distinguishes this segment from segment NT. Whereas mostly NT segment indicate on the lack of interest and the lack of financial assets.

For both segments the biggest advantages of being a prosumer are lower charges, savings and financial benefits. The environmental benefit is less important for both segments. People with a technical education also pointed to independence as a prosumer (it should be understood as an increase in energy security), non-technical people did not notice this aspect by choosing their motivations as motivators, but they pointed to own needs (they want to become a prosumer to satisfy their own needs).

Both segments pointed that the most important disadvantages of being a prosumer is neighbors' jealousy. They distinguished neighbors' jealousy as a disadvantage caused by being a prosumer (it was 
an open question). This fact suggests more conformity behaviors of the respondents. Only the T segment pointed out small subsidies as disadvantage of being a prosumer. Additionally, financial costs are the most important disadvantage for men with a technical education.

\subsection{Characteristics of Prosumers}

The most likely tendency to install RES is shown by households where a man of 30-49 years of age with a technical education is a decision maker who has an apartment with a floor area of over $80 \mathrm{~m}^{2}$. Compared to the similar segment of men, but with a non-technical education, it is clear that they are more likely to install energy-efficient equipment (see Figures 8 and 9) and they have higher knowledge about the energy sector (see Figure 7), but do not display such large pro-savings behaviors as men from the NT segment (see Table 7).

Characteristics of the two groups of potential prosumers according to abovementioned segmentation are summarized in Table 14. To point the most important features for each segment, the single answers were not taken to consideration in this table.

Table 14. Characteristic of separated segments.

\begin{tabular}{|c|c|}
\hline \multirow{6}{*}{ Segment $\mathrm{T}$} & $\begin{array}{l}\text { The main reason for installing RES is potential savings but the major reason for becoming a } \\
\text { prosumer is the possibility of extra earnings (including co-funding). Thus, it can be supposed that } \\
\text { these men are more entrepreneurial. }\end{array}$ \\
\hline & $\begin{array}{l}\text { They take care of the environment but financial aspects are more important for them. They are } \\
\text { open-mined people and are interested in technical novelties. }\end{array}$ \\
\hline & $\begin{array}{l}\text { The main barriers to installing RES and to becoming a prosumer are the lack of financial and } \\
\text { technical possibilities, complicated installation process, the lack of knowledge on the RES as well as } \\
\text { unclear legal regulations and financial inefficiency of small-scale generators installation. }\end{array}$ \\
\hline & $\begin{array}{l}\text { The potential savings and lower charges are advantages of being a prosumer. An additional } \\
\text { advantage is energy independency, in case of black-out. }\end{array}$ \\
\hline & Neighbors' jealousy is the main disadvantage and barrier to becoming a prosumer. \\
\hline & They have higher energy awareness and they are more likely to install energy-efficient equipment. \\
\hline \multirow{6}{*}{ Segment NT } & $\begin{array}{l}\text { The main reason for RES installing is potential savings but the main reason for becoming a } \\
\text { prosumer are savings and the possibility of extra earnings. }\end{array}$ \\
\hline & $\begin{array}{l}\text { Men indicate only on financial barriers to installing RES such as the lack of financial possibilities } \\
\text { and too expensive small-scale generators. }\end{array}$ \\
\hline & $\begin{array}{l}\text { The main barriers to becoming a prosumer are: High installation costs, complicated installation } \\
\text { process, lack of possibility and interest. }\end{array}$ \\
\hline & $\begin{array}{l}\text { The potential savings and lower charges are advantages of being a prosumer, such as energy } \\
\text { production for own needs, to ensure energy security. }\end{array}$ \\
\hline & $\begin{array}{l}\text { The good neighbor relationships are important for them, thus they do not like to distinguish } \\
\text { themselves and to arouse envy. }\end{array}$ \\
\hline & They behave pro-ecologically. \\
\hline
\end{tabular}

\section{Conclusions}

This paper explored the profile of end users of renewable energy sources (RES) among Polish households. Based on a literature review the main determinants of willingness to install small-scale RES were identified. The determinants were analyzed using empirical analysis with data collected by a survey among households in Poland. The significance of particular determinants were verified by the results of logit models.

It has been shown that there are significant relationships between a household's decisions about the RES installation and explanatory variables: Sex, age, number of people in a household, type of building, floor area, type of education, knowing energy tariff, sorting rubbish, washing or ironing at particular times, switching off electrical equipment if nobody uses, using LEDs and installing energy-saving home appliances. Extraordinary was that the logit model based on empirical data did 
not confirm a relationship between a household's decisions about the RES installation and monthly average net income, monthly expenditures on electricity and energy awareness variables (changing the provider, having a smart meter).

The end user segments were identified on the basis of the following determinants: Sex, age, floor area and technical or non-technical education. The characteristics of end user segments were created using survey questions concerning behavior and attitude of the respondents such as: The reasons for installing or not installing RES, factors that motivate to be of not to be a prosumer, the benefits and disadvantages of being a prosumer.

The research results can be used, for example, in advertising campaigns where a positive impact on the environment, good relationships with neighbors and long-term savings should be emphasized. The technical and economic education actions could be dedicated to the NT segment. In turn, T segment advertisements should point out good relationships with neighbors, and they should also refer to the expertise of the men themselves in this segment as well as possibilities of additional earnings as a prosumer. The advertisements and other promotional actions can refer to technical knowledge.

If local authorities endeavor to increase the share of small-scale RES regionally, the contribution of households should not be neglected. Their acceptance and willingness to install RES is crucial in increasing the share of RES installation. It is particularly important for a large part of Poland where $\mathrm{CO}_{2}$ emissions have to be reduced. The research results could be used to formulate social campaigns to overcome reluctance to install RES, prepare education trainings to overcome lack of knowledge and to show good practices calculating financial efficiency, to develop a clear and effective subsidy system, because financial and economic aspects are the most important for Polish society. Stable and clear regulation is also needed.

Future Works: In some papers the authors pointed to a relationship between willingness to install RES and degree of information on RES or difficulty of adoption. It will be interesting to verify significance of the variables by logit model by means of empirical data collected for Polish households. Another hypothesis that could be verified are relationship between willingness to install RES and type of heating system, source of hot water and area of residence. Concerning criteria of segmentation in future works, we could include a cluster analysis to obtain statistically correct segments. We could compare the results obtained by segmentation with results obtained by clustering.

Author Contributions: The two authors designed the research, conducted the research and investigation process, contributed to the data analysis, and participated in the preparation and revision of the manuscript.

Funding: This research was partially funded by the National Centre of Science (NCN, Poland), grant number 2013/11/B/HS4/01070 and by the National Center of Research and Development in Poland, the project "Developing a platform for aggregating generation and regulatory potential of dispersed renewable energy sources, power retention devices and selected categories of controllable load" supported by European Union Operational Programme Smart Growth 2014-2020, Priority Axis I: Supporting R\&D carried out by enterprises, Measure 1.2: Sectoral R\&D Programmes, POIR.01.02.00-00-0221/16, performed by TAURON Ekoenergia Ltd.

Acknowledgments: We thank the anonymous reviewers for their careful reading of the manuscript and their insightful comments and suggestions.

Conflicts of Interest: The authors declare no conflict of interest.

\section{Abbreviations}

The following abbreviations are used in this manuscript:

RES

T segment men with technical education

NT segment men with non-technical education

\section{References}

1. Central Statistical Office. Statistical Yearbook of the Republic of Poland 1996; Central Statistical Office: Warsaw, Poland, 1997.

2. GUS. Zużycie Paliw i Nośników Energii w 2015; GUS: Warszawa, Poland, 2016. 
3. Central Statistical Office. Energy Consumption in Households in 2015; Central Statistical Office: Warsaw, Poland, 2017.

4. Central Statistical Office. Environment 2016; Central Statistical Office: Warsaw, Poland, 2016.

5. Amador, F.J.; Gonzáles, R.M.; Ramos-Real, F.J. Supplier choice and WTP for attributes in an emerging market: The role of perceived past experience, environmental concern and energy saving behaviour. Energy Econ. 2013, 40, 953-966. [CrossRef]

6. Scarpa, R.; Willis, K. Willingness-to-pay for renewable energy: Primary and discretionary choice of British households' for micro-generation technologies. Energy Econ. 2010, 32, 129-136. [CrossRef]

7. Guo, X.; Liu, H.; Mao, X.; Jin, J.; Chen, D. Willingness to pay for renewable electricity: A contingent valuation study in Beijing, China. Energy Policy 2014, 68, 340-347. [CrossRef]

8. Batley, S.; Colbourne, D.; Fleming, P.; Urwin, P. Citizen versus consumer: Challenges in the UK green power market. Energy Policy 2001, 29, 479-487. [CrossRef]

9. Diaz-Rainey, I.; Ashton, J.K. Profiling Potential Green Electricity Tariff Adopters: Green Consumerism as an Environmental Policy Tool? Bus. Strategy Environ. 2011, 20, 456-470. [CrossRef]

10. Shin, J.; Hwang, W.-S. Consumer preference and willingness to pay for a renewable fuel standard (RFS) policy: Focusing on ex-ante market analysis and segmentation. Energy Policy 2017, 106, 32-40. [CrossRef]

11. Zarnikau, J. Consumer demand for green power and energy efficiency. Energy Policy 2003, 31, 1661-1672. [CrossRef]

12. Wiser, R.H. Using contingent valuation to explore willingness to pay for renewable energy: A comparison of collective and voluntary payment vehicles. Ecol. Econ. 2007, 62, 419-432. [CrossRef]

13. Rowlands, I.; Scott, D.; Parker, P. Consumers and green electricity: Profiling potential purchasers. Bus. Strategy Environ. 2003, 12, 36-48. [CrossRef]

14. Carlman, I. The views of politicians and decision-makers on planning for the use of wind power in Sweden. In Proceedings of the European Wind Energy Conference, Hamburg, Germany, 22-26 October 1984; pp. 339-343.

15. Bosley, P.; Bosley, K. Public acceptability of California's wind energy developments: Three studies. Wind Eng. 1988, 12, 311-318.

16. Upham, P.; Whitmarsh, L.; Poortinga, W.; Purdam, K.; Devine, W. Public Attitudes to Environmental Change-A Selective Review of Theory and Practice, Report for RCUK/LWEC. 2009. Available online: http:/ /www.lwec. org.uk/news-archive/2009/30102009-report-published-public-attitudes-environmental-change (accessed on 23 November 2018).

17. Shackley, S.; Reiner, D.; Upham, P.; de Coninck, H.; Sigurthorsson, G.; Anderson, J. The acceptability of $\mathrm{CO}_{2}$ capture and storage (CCS) in Europe: An assessment of the key determining factors: Part 2. The social acceptability of CCS and the wider impacts and repercussions of its implementation. Int. J. Greenh. Gas Control 2009, 3, 344-356. [CrossRef]

18. Yuan, X.; Zuo, J.; Ma, C. Social acceptance of solar Energy technologies in China-End users' perspective. Energy Policy 2011, 39, 1031-1036. [CrossRef]

19. Kowalska-Pyzalska, A. An Empirical Analysis of Green Electricity Adoption Among Residential Consumers in Poland. Sustainability 2018, 10, 2281. [CrossRef]

20. Federacja Konsumentów. Jak zostać prosumentem. Raport Federacji Konsumentów. Available online: http:/ / www.federacja-konsumentow.org.pl/n,159,1307,91,1,raport-federacji-konsumentow.html (accessed on 26 January 2016).

21. Kryk, B. (Ed.) Ekonomiczne, Ekologiczne i Społeczne Problemy Wykorzystania Energii w Gospodarstwach Domowych; Rozprawy i Studia, Uniwersytet Szczeciński: Szczecin, Poland, 2016; Volume MXXXII, No. 958; ISBN 978-83-7972-101-6.

22. Nycz-Wróbel, J. Zachowania ekologiczne w gospodarstwach domowych (na przykładzie opinii mieszkańców woj. podkarpackiego), Zeszyty Naukowe Politechniki Rzeszowskiej. Mod. Manag. Rev. 2012, 19, 39-50. Available online: http:/ / doi.prz.edu.pl/pl/publ/zim/24 (accessed on 5 August 2017). [CrossRef]

23. Słupik, S. Świadomy konsument energii w województwie śląskim w świetle badań ankietowych. Studia ekonomiczne. Zeszyty Naukowe Uniwersytetu Ekonomicznego w Katowicach 2015, 232, 215-236.

24. Da Silva, P.G.; Karnouskos, S.; Ilic, D. A Survey Towards Understanding Residential Prosumers in Smart Grid Neighbourhoods, Innovative Smart Grid Technologies (ISGT Europe). In Proceedings of the 3rd IEEE PES International Conference and Exhibition, Berlin, Germany, 14-17 October 2012. Available online: http:/ /ieeexplore.ieee.org/document/6465864/ (accessed on 5 August 2017). [CrossRef] 
25. Central Statistical Office. Demographic Yearbook of Poland; Central Statistical Office: Warsaw, Poland, 2016.

26. Babbie, E. Badania społeczne w praktyce; Wydawnictwo naukowe PWN: Warszawa, Poland, 2004.

27. Ropuszyńska-Surma, E.; Weglarz, M. The pro-economical behaviour of households and their knowledge about changes in the Energy market. In Proceedings of the International conference Energy and Fuels, Krakow, Poland, 21-23 September 2016. [CrossRef]

28. Ropuszyńska-Surma, E.; Węglarz, M. Social acceptance of renewable energy sources in Poland-Guidelines for educational process. In Proceedings of the 9th annual International Conference on Education and New Learning Technologies, Barcelona, Spain, 3-5 July 2017. Available online: https:/ /library.iated.org/ publications/EDULEARN17 (accessed on 23 November 2018). [CrossRef]

29. Ropuszyńska-Surma, E.; Weglarz, M. The identification of factors influencing on future prosumers. Studia $i$ Prace WNEiZ US 2018, 54, 331-346. (In Polish) [CrossRef]

30. Ropuszyńska-Surma, E.; Węglarz, M. Bariery rozwoju energetyki rozproszonej. Przegląd Elektrotechniczny 2017, 4, 90-94.

31. Central Statistical Office. National Census 2011; Central Statistical Office: Warsaw, Poland, 2014.

32. Central Statistical Office. Living Conditions of Families in Poland; Central Statistical Office: Warsaw, Poland, 2014.

33. Central Statistical Office. Gospodarstwa Rolne w Polsce na tle Gospodarstw Unii Europejskiej-Wptyw WPR; Central Statistical Office: Warsaw, Poland, 2013; ISBN 978-83-7027-539-6.

34. Bargiel, J.; Sowa, P.; Zając, K.; Sierociński, T. Sposoby poprawy niezawodności w sieci średnich napięćPolityka energetyczna gmin. Rynek Energii 2011, 2, 95-101.

(C) 2018 by the authors. Licensee MDPI, Basel, Switzerland. This article is an open access article distributed under the terms and conditions of the Creative Commons Attribution (CC BY) license (http:/ / creativecommons.org/licenses/by/4.0/). 